\title{
BLACK-TAILED GODWIT SIGHTED \\ NEAR REGINA — FIRST FOR INTERIOR NORTH AMERICA
}

\section{FRANK H. BRAZIER, 2657 Cameron Street, Regina, Saskatchewan. S4T 2W5}

Saturday, 14 July 1990 , was a beautiful day and at 3:30 p.m. the sun shone brightly. My wife, Marjie, and I drove south on the road across Brown's Slough, which is about $12 \mathrm{~km}$ northwest of Regina as the crow flies, and a good place for shorebirds. We saw a couple of Stilt Sandpipers, a Greater Yellowlegs, and, close by the latter, a wader which was noticeably larger and with more of its legs visible above the water. It was feeding avidly using its long, straight bill (about twice the length of the head) to seize prey. As I focused my binoculars on it, I knew that I had never seen this bird before.

I snatched up my telescope and focused on it. I could see that the bill was bi-coloured, the basal half being dull yellow and the rest black. The plumage was generally light grey, much like a Willet. While it fed mostly by picking from the surface, on three occasions it spied prey about $2 \mathrm{~m}$ away and below the surface (as I could see nothing), ran toward it and seized it without submerging the head. I got the impression it was a very hungry bird! On the third run at prey it stopped close to an emergent clod of earth, and climbed on top of it where it stretched itself and looked around. I was amazed at the inordinately long legs it displayed which appeared to be the colour of an Avocet's, greyish-blue.

All the time we watched it the wings were never opened but I could see a horizontal black line formed by the closed primaries and secondaries. The bird changed position on the clod twice so I could see that the tail was solid black at the distal end and white basally, the white extending up the rump. I could see no pattern or colour on the uniformly pale grey body, grey sides of the chest and white underparts. Regrettably, time was pressing so we had to leave. I had no idea of the bird's identity but I thought I had sufficient field marks to allow me to find its name without trouble.

We were home by 4:30 p.m. and although I made numerous phone calls I could locate no one who could go out and check my find. I returned to Brown's Slough at 7:30 p.m., but could not relocate the bird.

At home I went through most of my bird guides but could find no picture to match my bird. Next morning over coffee with Fred Lahrman I described it and he suggested that the bi-coloured bill would make it one of the godwits, of which there are four species. That evening I checked further and this time I found it. Slater, Plate 41, shows a Blacktailed Godwit (Limosa limosa) agreeing essentially with the bird I saw. ${ }^{12}$ The text on pp. 85 and 308 describe it as having a long, straight bill, the legs and feet being greenish-grey (the legs in the painting seem to be grey). I now realized that this godwit does not always have an upturned bill. The author states: "RANGE - Breeds in temperate regions of Eurasia. Non-breeding birds disperse south to Africa, southem Asia, and Australasia." Slater's bird is a non-breeder and in 
winter plumage, which mine would also be. The legs of the bird are shown to be exactly the same length as those of the adjacent Bar-tailed Godwit (L. lapponica) in the plate, whereas he states that the legs of the Black-tailed Godwit are longer than those of the Bar-tailed. I located a photograph of a Black-tailed Godwit in Smith showing it perched on a post; the legs appear to be twice as long as the body depth. ${ }^{13}$

Hollom depicts the legs to be about twice the body depth, much like my bird. ${ }^{5}$ Indeed, Hollom states: "...its longer legs give it a noticeably taller, more upstanding appearance, in contrast to Bar-tailed whose legs look rather short for the bird's size; and its bill is longer and quite straight or only very faintly upcurved" (p. 200). ${ }^{5}$ Elsewhere he says the bill is pink basally shading to black.

I was puzzled to find that published accounts of leg colour varied. In Chandler's four photographs (one juvenile, three adults) they appear to be lead-grey (juv.) and black (adults). ${ }^{1}$ Cramp for adults and juvenile states: "Legs and foot lead-grey to black with olive tinge." 2 Hollom says the legs are greenish-black. ${ }^{5}$ Peterson et al. does not describe the leg colour but in the painting the legs appear to be black. ${ }^{8}$ Prater et al. state: "Legs dark greyish." Scott does not describe leg colour but they appear to be dark grey in the paintings. ${ }^{11}$ Slater states: "Legs and feet greenishgrey." 12 None of these descriptions or pictures come close to matching the shiny greyish-blue legs on my bird. However, in R.S.P.B. Chart No. 7, the Blacktailed Godwits clearly show their long greyish-blue legs. ${ }^{10}$ Chandler remarks that "general coloration varies with age and season" are enlightening. Perhaps my bird was a young one and its bill will turn up slightly and its legs darken as it matures.

The feet and other soft parts of dead birds darken in relatively short time. Bird book illustrators painting from museum specimens and unfamiliar with the birds in life could unintentionally produce an inaccurate picture.

In July, Saskatchewan shorebirds are already moving south, and some will have lost their spring plumage, so I have to consider the possibility that my Blacktailed Godwit was actually a Hudsonian Godwit. While Scott does say that they resemble each other in winter plumage, Prater et al. give measurements to show that the Black-tail is the larger bird and the length of the tarsus is greater. 9,11 Godfrey also notes that it is larger. ${ }^{4} \mathrm{My}$ bird had inordinately long legs whereas the Hudsonians I have seen never struck me that way. Specimens in the Saskatchewan Museum of Natural History and the paintings of the Hudsonian in winter plumage in Scott, ${ }^{11}$ Peterson ${ }^{7}$ and Lowery ${ }^{6}$ all show that it has a narrow white terminal band to the black tail whereas my bird lacked that feature; the terminal part of its tail was black to the end.

I have examined the "Index of Boldfaced Birds" in American Birds from 1967 to 1989 (Vols. 21-43) without finding a single mention of Black-tailed Godwit in interior North America. If one looks at the plates in the two Peterson field guides depicting the Black-tailed Godwit in flight (p. 94) and the Willet in flight (p. 115) the resemblance is amazing. ${ }^{8,7}$ If a Black-tailed Godwit flew with a flock of fall Willets it could easily be overlooked.

Elkins, discussing the probable effect of global warming on British birds in the next 40 years, points out that ice-melt would adversely affect waders by reducing their coastal and estuarine habitats. ${ }^{3}$ During this process there would be weather pattern changes which, in turn, would possibly disrupt migrations and increase vagrancy. Right now vagrants are being recorded at remarkable fre- 
quencies all over and no one knows how many escape detection. We should all be prepared to recognize a vagrant when it crosses our paths and then be able to identify it. This means our personal libraries should have a good selection of foreign field guides to increase our familiarity with birds around the world, especially those which are likely to reach our personal birding areas.

Godfrey points out that the Blacktailed Godwit and the Hudsonian Godwit can only be separated by the underwing colours but this is in the context of flying birds. ${ }^{4}$

As I did not take it as a specimen nor did I photograph it, I offer the BlackTailed Godwit as an addition to the Hypothetical List of Saskatchewan Species.

1. CHANDLER, RICHARD. 1989. The Facts on file guide to North Atlantic shorebirds. Facts on File, New York.

2. CRAMP, STANLEY, et al. 1983. Handbook of the birds of Europe, the Middle East and North America. Vol. III. Oxford University Press, Oxford.

3. ELKINS, NORMAN. 1990. What does global warming mean for our birds? Scottish Bird News, June, 1990. Scottish Ornithologists's Club, Edinburgh.

4. GODFREY, W. E. 1986 Birds of Canada. Rev. Ed., Natl. Mus. Canada, Ottawa.

5. HOLLOM, P.A.D. 1962. The popular handbook of British birds. H.F.G. Witherby, London.
Louisiana State Univ. Press, Baton Rouge.

7. PETERSON, R.T. 1961. A field guide to western birds. Houghton Mifflin, Boston.

8. PETERSON, R.T., GUY MOUNTFORT, and P.A.D. HOLLOM. 1954. A field guide to the birds of Britain and Europe. Houghton Mifflin, Boston.

9. PRATER, A.J., J.H. MARCHANT, and J. VUORINEN. 1977. Guide to the identification and ageing of Holarctica waders (B.T.O. Guide 17). British Trust for Ornith, Beach Grove, Tring, Herts., England.

10. Royal Society for the Protection of Birds. Chart No. 7, Shorebirds and waders. Royal Society for the protection of Birds. The Lodge, Sandy, Beds., England.

11.SCOTT, S.L. 1987. Field guide to the birds of North America. Nat. Geo. Soc., Washington, D.C.

12. SLATER, PETER. 1972. A field guide to Australian birds. Vol. I - Nonpasserines. Rigby, Adelaide.

13. SMITH, S. 1970. Wild wings to the northland. H.F.\& G. Witherby, London.

Ed. Note: From another source, Black-tailed Godwit legs are describes as "long, dark grey or blue-grey." Total length and tarsus of the Black-tailed Godwit are given as 360-440 mm and $59-96 \mathrm{~mm}$, respectively; for Hudsonian Godwit, they are $370-420 \mathrm{~mm}$ and $52-72 \mathrm{~mm}$. HAYMAN, MARCHANT, and PRATER. 1986. Shorebirds - An identification guide to the waders of the world. Houghton Mifflin, Boston. 412 pp.

6. LOWERY, H. Jr. 1960. Louisiana birds.

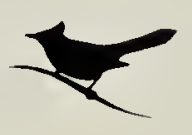

Stone is storyteller.

Stone is meditation master.

Stone performs the dance of stillness.

F. Lehrman. 1988. The Sacred Landscape. Celestial Arts, Berkeley, CA. 